\title{
NANGARHAR
}

\section{EMERGENCY REPORT}

(JALALABAD, SORKH ROD, BEHSUD, CIIAPARIIAR, SIIEWA AND KAMA)

\section{$\Lambda \mathrm{CB} \Lambda \mathrm{R}$}

EARLY MAY 1992 
INTRODUCTION

BACKGROUND.

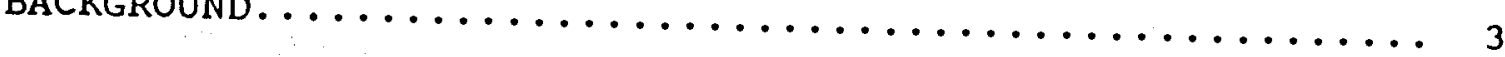

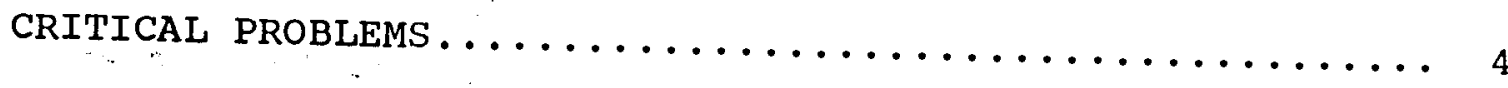

SURVEYED AREAS

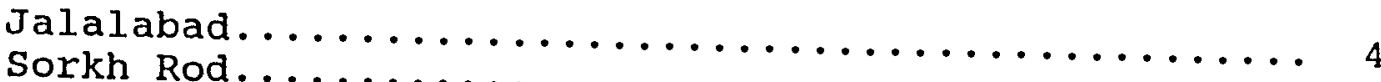

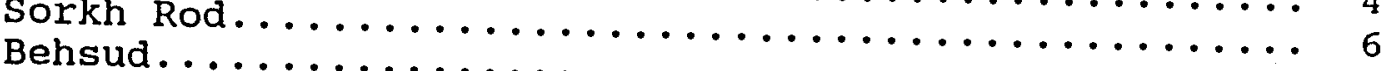

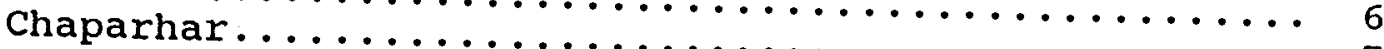

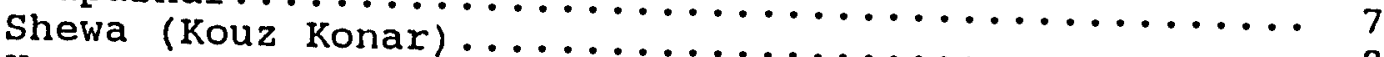

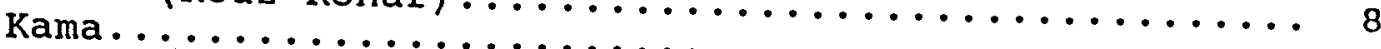

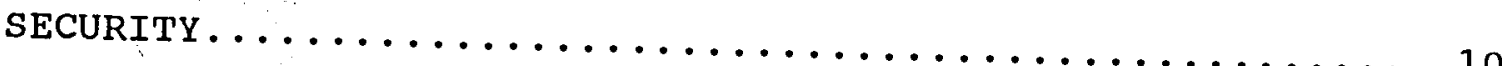

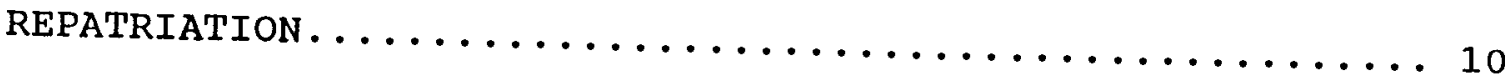

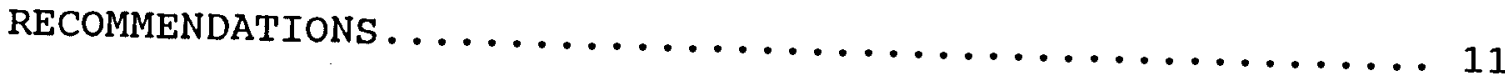

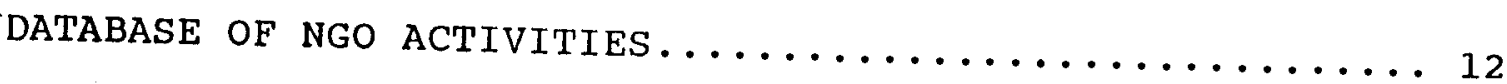

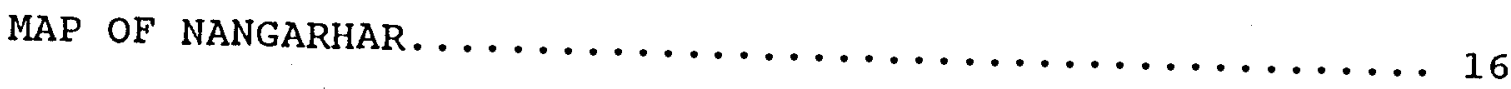




\section{INTRODUCTION :}

The aim of this report is to highlight the emergency needs of the areas which have recently fallen into mujahideen hands (Jalalabad city
and its surrounding areas).

In the last Nangarhar coordination meeting, sunday April 26, 1992 at ACBAR, it was agreed to send a joint team to conduct a quick assessment to find out the urgent needs and forward the findings to those interested in providing assistance for the area.

The team was also supposed to talk to the new authorities in the province and find out their views regarding the future cooperations between the agencies and the authorities.

The team was composed of:

1. Ismail of MADERA to survey shewa and Kama

2. Sayed Habiburahman of ARR to survey Jalalabad and Sorkh Rod

3. Mohd Ismail of CRAA to survey Chaparhar

4. Mohd Ayaz Haidarzai of ISRA to survey Behsud.

It was a three day survey (April 28 - May 1, 1992).

The report also contains some information from staff of different agencies (other than those listed above) and individuals who have recently visited the province.

Shakir

ACBAR 


\section{BACKGROUND :}

Nangarhar is the second largest province in Afghanistan from a population point of view. One third of the approximately one million population of the province belongs to Jalalabad city and areas over the years such as Behsud, Sorkh Rod, Chaparhar, Kama \& Shewa. fled to pakistan war the majority of inhabitants of these areas have people from who were affilferent parts of Nangarhar as well as Kunar and Laghman who were affiliated to the communist regime had gone to Jalalabad.

\begin{tabular}{|c|c|c|c|c|c|}
\hline $\begin{array}{l}\text { DISTRICT } \\
\text { NAME }\end{array}$ & $\begin{array}{c}\# \text { OF } \\
\text { VI LLAGES }\end{array}$ & $\begin{array}{r}\text { AREA } \\
\text { SQ.KM. }\end{array}$ & $\begin{array}{l}1990 \text { PROJ } \\
\text { POPULATION }\end{array}$ & $\begin{array}{l}\text { REFUGEE } \\
\text { (family) }\end{array}$ & $\begin{array}{l}\text { POPULATION PRESENT } \\
\text { AT SURVEY TIME }\end{array}$ \\
\hline $\begin{array}{l}\text { JALALABAD } \\
\text { SORKH ROD } \\
\text { BEHSUD } \\
\text { CHAPARHAR } \\
\text { KAMA } \\
\text { SHEWA }\end{array}$ & $\begin{array}{r}50 \\
100 \\
41 \\
29 \\
56 \\
39 \\
\end{array}$ & $\begin{array}{l}236 \\
384 \\
220 \\
184 \\
229 \\
327\end{array}$ & $\begin{array}{r}60,731 \\
101,105 \\
60,827 \\
41,270 \\
51,622 \\
38,448\end{array}$ & $\begin{array}{r}86 \\
1,242 \\
7,967 \\
5,953 \\
6,498 \\
2,739\end{array}$ & $\begin{aligned} & 800,000 \text { people } \\
& 700 \text { families } \\
& 3,250 \text { families } \\
& \text { no families } \\
& 360 \text { families }\end{aligned}$ \\
\hline TOTA L : & 315 & 1,580 & 354,003 & $24,485^{1}$ & \\
\hline
\end{tabular}

In the past couple of years since the mujahideen captured all parts of the province except Jalalabad city, the above-mentioned areas have been heavily devastated due to continuous fighting between mujahideen and communist troops. In most parts security posts were established and different types of mines and explosive materials were placed around the posts. A vast area not only has not been cultivated but has become barren because of weeds.

A number of NGOs have been providing humanitarian services in other parts of Nangarhar (mujahideen held areas). The government facilities were only limited at the level of Jalalabad city. In light of the above mentioned points one could, without any assessment, imagine how the situation is in the area.

1. An average family in Nangarhar is 7-10. 
Internally displaced people would return to their houses at first. The refugees from Pakistan have also started moving or at least sending a member of the family to see the houses and possibilities of returning. According to UNHCR repatriation statistics 10,591 people have returned to the surveyed areas. Many more will return as soon as the critical problems are solved.

\section{CRITICAL PROBLEMS:}

Mines are one of the most critical problems. Since the fall of Jalalabad into mujahideen hands more than 150 people have been blown up. MMC, the first health facility has moved to Jalalabad, has reported that almost all of the patients received were mine-injuries.

From Pul-e-Barikab to Samarkhel (Sorkh Dewar \& Bagh-e-Kalaksion areas), both sides of the international road (Torkham-Jalalabad) is mined. This is a serious problem not only for people of Nangarhar but for all those who use the road and pass to other provinces e.g. returnees. Four vehicles have been blown up so far. Now drivers are afraid to leave the track on the road which sometimes creates a blockage when two vehicle pass.

There are damaged bridges on the main road between Barikab bridge and Hisar shahi turning point. The vehicles have to leave the road and drive about two $\mathrm{km}$ off-road in flash floods. Moreover, the main Torkham-Jalalabad road and further to Kabul has been damaged which has slowed down the transportation. Before the war, the trip between Torkham and Jalalabad took the buses one and half hours while now it takes them more than 3 hours.

\section{SURVEYED DISTRICTS}

\section{JALALABAD}

Jalalabad is divided into four divisions(Nahia) currently housing a population of around 800,000 people most of whom do not originally belong to Jalalabad. In addition to the inhabitants of the city, there are many visitors and travellers both from Peshawar and Kabul which has overcrowded the city. The economical condition of most people is in a bad shape. Although the price of most commodities decreased after liberation of the city, many people can still not afford their daily expenses. The following is a list of prices of some goods before and after liberation of Jalalabad: 
ITEM

1. Flour

2. Cooking oil

3. Sugar

4. Rice first class

5. Rice second class

6. Salt

7. Potato

8. Tomato

9. Eggplant

10. Peas

11. Grass pea

12. Green tea first class

13. Green tea second class

14. Black tea

15. Beans

16. Pepper

17. Beef

18. Onion

19. Chicken
PRICE BEFORE

LIBERATION

3,500 Afs. $/ 7 \mathrm{~kg}$.

8,000 Afs. $/ 5 \mathrm{~kg}$.

4,000 Afs. $/ 7 \mathrm{~kg}$.

4,000 Afs. $/ 7 \mathrm{~kg}$.

3,000 Afs. $/ 7 \mathrm{~kg}$.

1,000 Afs. $/ 7 \mathrm{~kg}$.

2,500 Afs. $/ 7 \mathrm{~kg}$.

not available

not available

1,000 Afs. $/ 1 \mathrm{~kg}$.

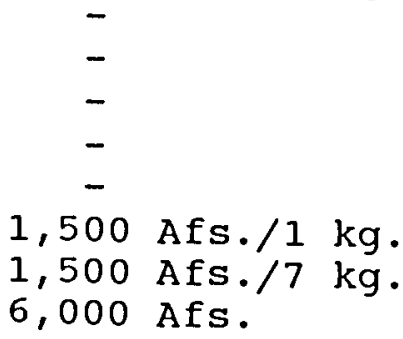

PRICE AFTER

LIBERATION

\begin{tabular}{|c|c|}
\hline 10 & 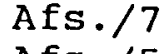 \\
\hline .000 & Afs. $/ 5$ \\
\hline, 000 & Afs./7 \\
\hline .800 & Afs. $/ 7$ \\
\hline, 800 & Afs./7 \\
\hline 300 & Afs. $/ 7$ \\
\hline, 100 & Afs./7 \\
\hline .000 & Afs. $/ 7$ \\
\hline., 000 & Afs. $/ 7$ \\
\hline, 000 & Afs. $/ 7$ \\
\hline 300 & $/ 1$ \\
\hline 4,500 & Afs./1 \\
\hline 3,600 & Afs./1 \\
\hline 4,000 & Afs./1 \\
\hline 800 & Afs \\
\hline 500 & $/ 1$ \\
\hline 700 & Afs./1 \\
\hline $\begin{array}{l}1,000 \\
1,500\end{array}$ & $\begin{array}{l}\text { Af } \\
\text { Af }\end{array}$ \\
\hline
\end{tabular}

Mines:

The areas from Farm Ada to Akhundzada Sahib is mined especially around Jui 3 and Jui 5. Some 400 jeribs of land are mined in Bagh Kalaksion. Around the Airport, except the two entrances, is completely mined and very dangerous. The entire area is covered by wire nets.

\section{Health:}

Both government hospitals (Public Health Hospital and University Hospital) are functioning. There are some 580 staff in both hospitals out of which 236 are health workers (62 doctors, 174 nurses). Most of the staff attend their work. However, the hospitals need supplies
e.g. medicine.

Moreover, some NGOs have moved their health facilities to the city:

1. Mujahid Medical Center has shifted its clinic from Mazina to the Red Crescent Hospital building. This is primarily for wounded people, however, it serves the local population as well.

2. Afghanistan Nothilfe has shifted its facilities from Peshawar to Jalalabad city (Hostel of Nursing School).

3. 2 Arabic Organizations.

There are many private medical stores in the city and also the doctors employed by the government have their private clinics. 


\section{Others:}

Houses in the suburbs of Jalalabad such as Khush Gumbad and Qasaba have been more than $70 \%$ demolished. Buildings and houses inside the
city have received some minor damage.

Nahri Shahi (10 km) dam has been damaged. It needs to be repaired to assure restoration of irrigation water for a vast agricultural area.
Jui 7 has also been damaged and needs rehabilitation.

\section{SORKH ROD:}

Sorkh Rod is the second largest district of Nangarhar from a population point of view. It is also one of the districts which have the highest number of refugees. Some returnees were noticed going to

In a small portion of the district in the west some NGOs were providing some small quantities of assistance but most parts of the
districts were not reachable. Mines:

The biggest problem in Sorkh Rod district is the mine fields which started from Khar Karan Base up to Bawli and Fateh Abad, about 8 to 10 which left 6 dead and 6 wounded.

\section{Health:}

No health facilities were seen in the newly liberated part of sorkh

\section{Others:}

$70-80 \%$ of the houses in the newly liberated part of sorkh Rod has been
damaged. Jui Ghawchak and Jui Mirzayan need rehabilitation.

\section{BEHSUD:}

Currently approximately 700 families live in Behsud out of which 400 jerib agricultural land but only a quarter. There is some 60,000 (mainly wheat and vegetable). 


\section{Mines:}

The villages of Banaghar, Shekihan, Tangi, Oach Tangi and Gharban are heavily mined.

\section{Health:}

No health facilities were seen.

\section{others:}

Approximately $90 \%$ of the houses/buildings in Behsud has been destroyed. The remaining $10 \%$ need some small repair and renovation.

The following irrigation systems need to be repaired:

3 intakes from Kabul River at Behsud, Bahar Abad and Qasim Abad
plus their channels.

- 2 intakes from Kunar River at Tangi Abdul Khel plus their channels.

The people at present use river water for drinking. The wells existing before have collapsed. Digging of drinking water wells is needed.

The main road from Behsud bridge to Tangi Abad Khel is $20 \mathrm{~km}$ and needs to be repaired.

\section{CHAPARHAR:}

Part of Chaparhar which includes Mano, Ediakhel, Banda, Dago, Shulana and Lawagapur areas has not been much affected by the war. Agricultural lands have been cultivated in these villages and some NGOs have been providing assistance to the area.

The remaining part of the district (Dawlatzai, Qala Shekah, Bibi Mahro, Hada, Ghazo Kali, Hafizan, Taralai, Kandi Bagh, Tarakai, Lalma, Saracha, Karez Kabir and Samar Khel) was most of the time under control of the ex-regime. Continuous fighting was going on in this part, consequently the area has been completely damaged. The inhabitants are refugees mainly in Pakistan.

\section{Mines:}

There are mine-fields in the villages of Sera Qala Ghorabad, shuaib Kali, Dawlatzai, Ghazo Kali (Gazak, Bibi Adi, Loi Burj, Margh Shah, Ghundi Sera areas), Taraki (Mula Kali), Bibi Mahro, Lalma (Perkand), Karez Kabir(Petaw Amar Khel), Samar Khel. 


\section{Health:}

No health facilities were seen in the villages listed the second paragraph.

\section{others :}

80 to 90 percent of the houses have been destroyed in the villages listed under second category.

The irrigation systems have been annihilated. The following irrigation systems located in different villages need rehabilitation:

- 18 intakes

- 53 karezes

- 6 springs

The agricultural lands are totally unfit for cultivation due to heavy bombardments and presence of mines.

\section{SHEWA (KOUZ KUNAR)}

Shewa is located $20 \mathrm{~km}$ to the south of Jalalabad. The area is vacant and the people have gone to Pakistan or Jalalabad. Some 360 families currently live in the area out of which only 60 are from the area and the remainder have come from other parts of the province. However, it was noticed that individual refugees were visiting the area and seeing the possibilities of returning with their families.

\section{Mines :}

Existence of mines is a problem in Shewa too. Many animals have been killed by mines. The villages of said Khel, Hashmat khel, Yasin Kali, Bibwari, Abdul khel and Tangi have mines.

\section{Health:}

No health facilities were seen.

\section{Others:}

80 to 90 percent of the houses have been damaged. A high school building has been destroyed.

The village of Shagah is being threatened by the Kunar River. The village which has some 400 jeribs agricultural land will be flooded. Some $200 \mathrm{~m}$ gabion work will save the village.

The main canal of Shewa (Jui Kalan Shewa) which provides irrigation water for 15 villages has been damaged and needs repair and rehabilitation. 
KAMA:

Kama is located $30 \mathrm{~km}$ to the east of Jalalabad city. No families were living in the district at the moment. However, it was noticed that individual refugees were visiting the area and seeing the possibilities of returning with their families.

Mines :

Mines are not a significant problem in Kama.

Health:

No health facilities were seen in the area.

others:

70 to 80 percent of the houses have been destroyed. Also 2 school buildings (a primary and a secondary) have been damaged and need to be repaired.

The main canal of Kama has been destroyed. The ex-regime had started rehabilitation of the canal but could not complete it. The canal needs to be repaired.

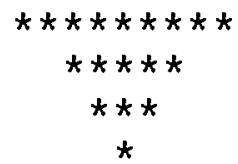

Regarding the second objective of the team "finding out the policy of the authority of the province on cooperation with NGOs" a letter will soon come from Haji Qadeer. The issue will also be discussed in the next Nangarhar coordination meeting on May 20, 1992.

Representatives from the new Governor and head of the ruling shura, Haji Qadeer, have expressed their concern at the number of NGOs who individually are trying to obtain some kind of agreement with his office. He has requested that a single authority - most appropriately ACBAR - acts as the intermediacy between himself and the NGOs. Agencies are urged to pay attention to this request as a means of assisting an already over-stretched administration in Jalalabad. 


\section{SECURITY:}

The security has been very good in the surveyed areas. Jalalabad is controlled by the allied shura of all mujahideen parties headed by Haji Qadeer of Hizb-e-Islami Khalis who is now acting as the governor of Nangarhar. Shamali of National Islamic Front of Afghanistan-NIFA is the incharge for the security. No incidents of insecurity have been reported so far.

There are check-posts at the exit points of Jalalabad city to prevent taking public belongings out of the city.

Some NGOS (IHSAN, MMC, Afghanistan Nothilfe) have already shifted their offices/facilities to Jalalabad city. others have sent their representatives to see the possibilities of opening/shifting offices.

\section{REPATRIATION:}

UNHCR EDP De-registration Database indicates repatriation to the surveyed areas as follows:

PERIODIC REPORT AS AT 2/4/1992

DISTRICT
FOR THE PERIOD

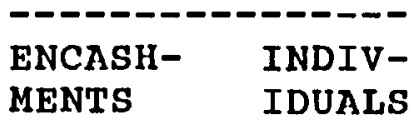

CUMULATIVE

$\begin{array}{ll}\text { ENCASH- } & \text { INDIV- } \\ \text { MENTS } & \text { IDUALS }\end{array}$

366

360

97

325

141

597

1,962

2,036

564

1,963

753

3,313
154

53

97

584

1,886

\section{9}

\section{1,886}


RECOMMENDATIONS

1. A demining program should be organized as soon as possible starting the operation from surkh Dewar area (both sides of the International Torkham-Jalalabad Road).

2. Food commodities other than wheat (cooking oil, sugar etc.) should be distributed in the surveyed areas. Distribution of wheat is not recommended because of two reasons:

A. Provision of more wheat in Nangarhar will decrease the price of wheat and thus the farmers will continue cultivating
opium poppy.

B. Returning refugees receive some wheat through the encashment program of UNHCR (de-registration). They do not receive other food commodities.

NOTE: WFP has already distributed $50 \mathrm{MT}$ wheat in Jalalabad through Kohi Noor Foundation and plans to distribute $250 \mathrm{MT}$ more
through ARR.

3. The two bridges between Barikab Bridge and Hisar Shahi bifurcate should be repaired. The main Torkham-Jalalabad road and if possible further to Kabul should also be repaired.

4. Health facilities should be established one in each surveyed district. Medical supplies e.g. medicine should be provided to the government hospitals in Jalalabad.

5. A detailed survey of each district should be conducted as soon as the areas are demined.

4. Temporary shelter for returnees should be provided in form of tents and tarpaulins. A housing program (provision of beams and slabs) should be considered in the surveyed areas.

5. Irrigation systems should be rehabilitated giving priority to those mentioned under different districts.

6. Diesel operated flour mills should be established namely in Chaparhar, shewa, Kama and sorkh Rod.

7. Agricultural inputs such as improved seeds and fertilizer should be provided. 


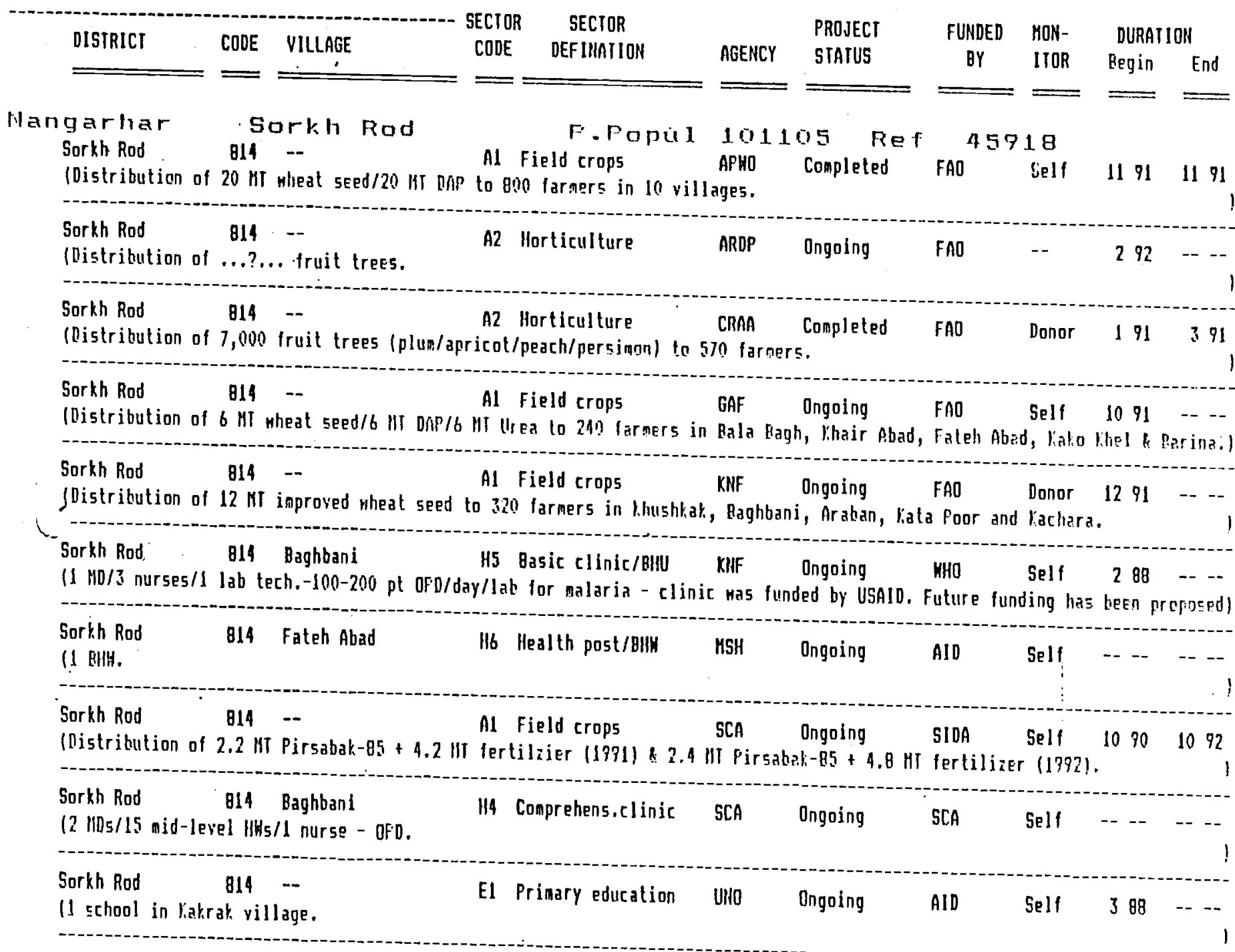




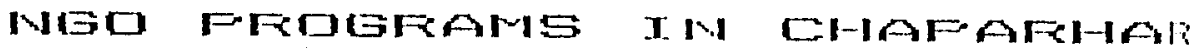

PROJECT LOCATION

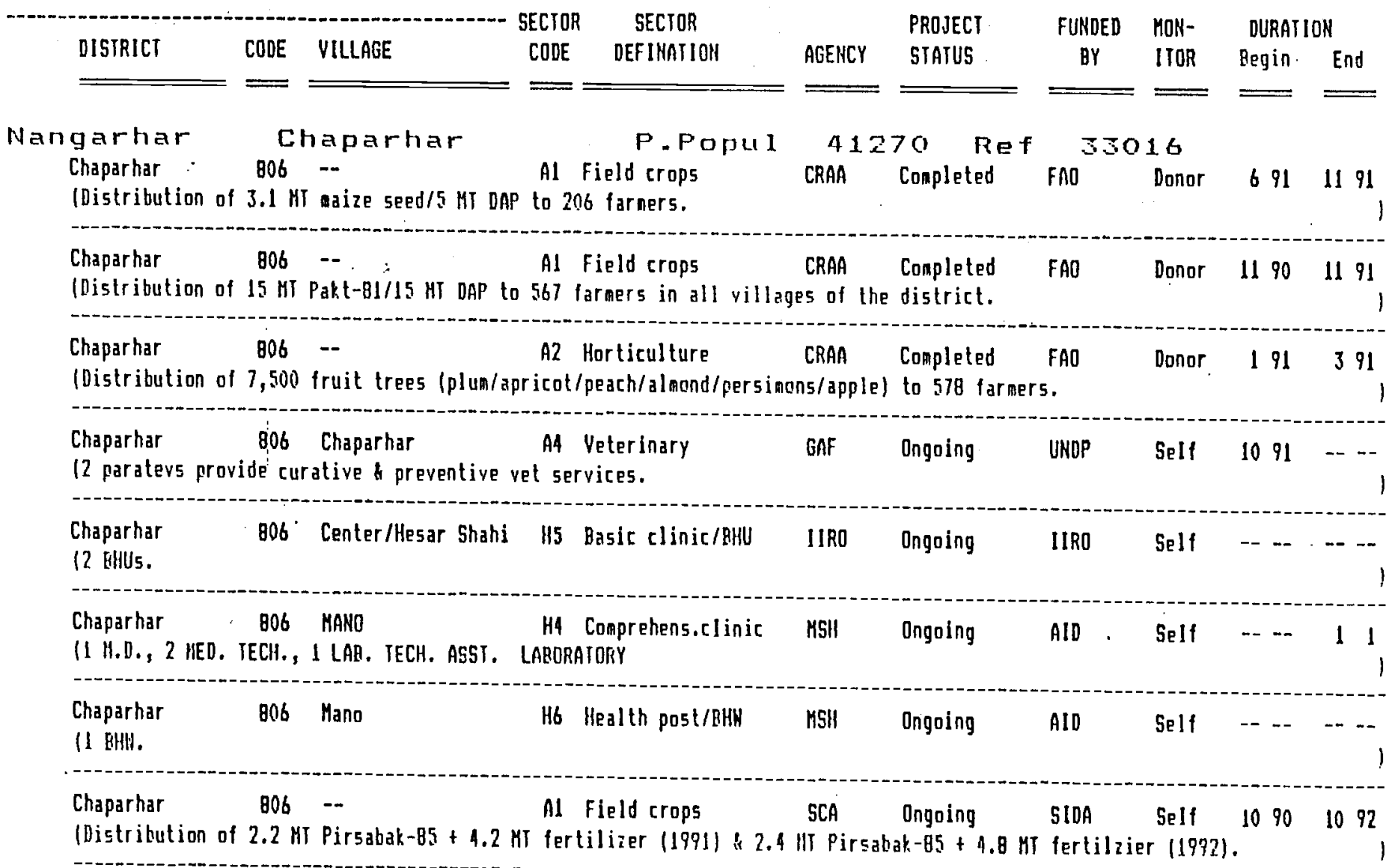


PROJECT LOCAIION

DISTRICT

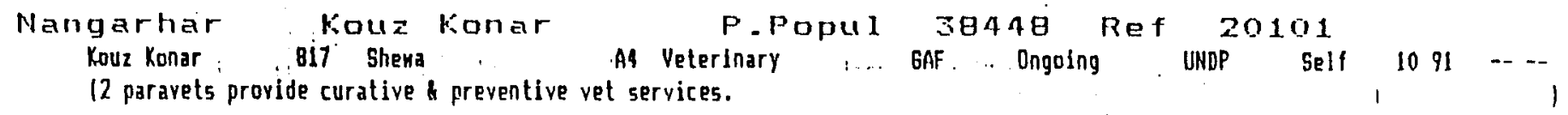
Kouz Konar :B17 -- El Priary education UNO Ongoing Al0 Self 388 -. --

14 schools in Badal, Shalnat, Shagandol t liechand villages. 
PROJECT LOCAIION

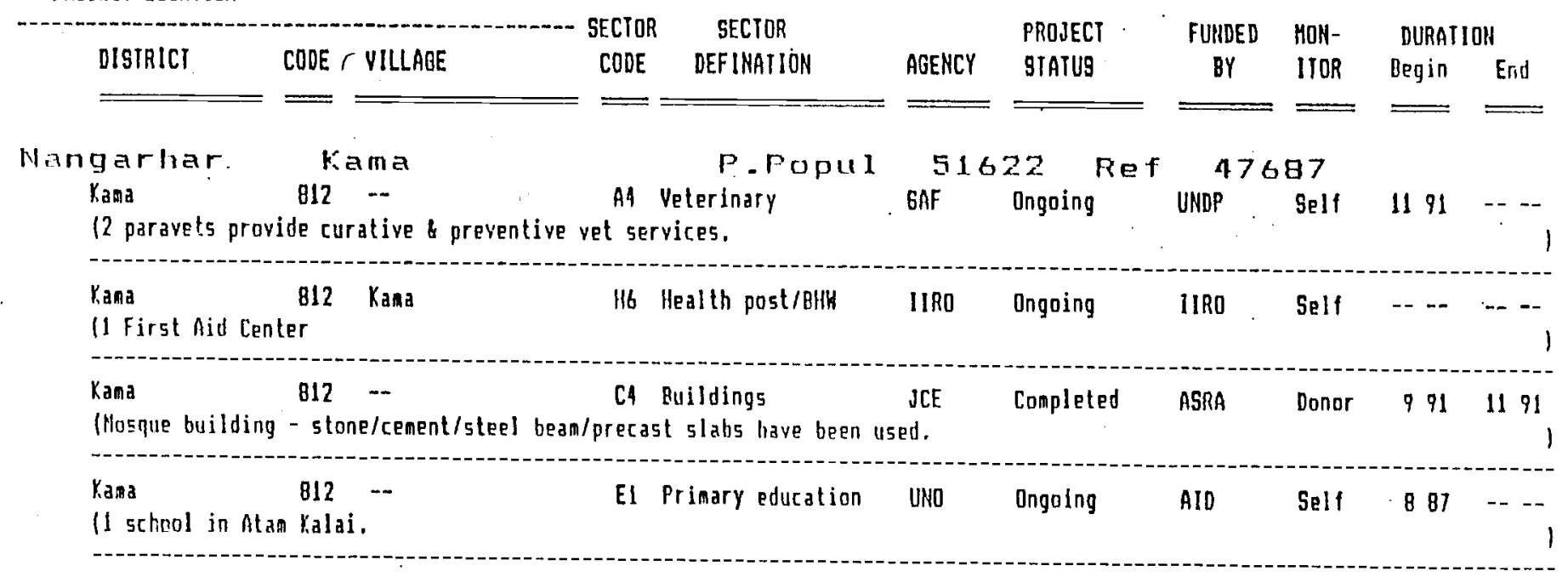




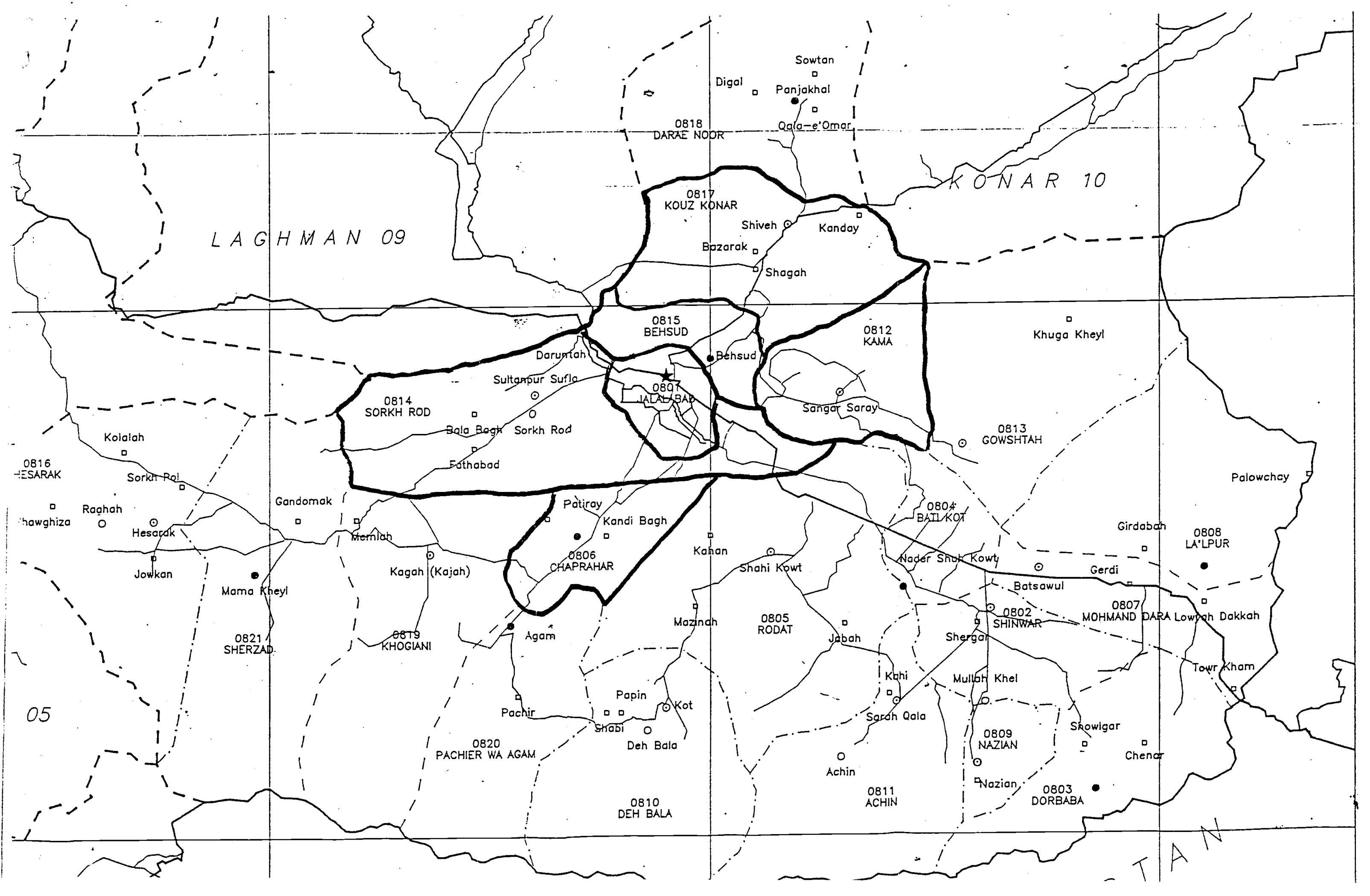

